\title{
Colonial Forest Policies and Tropical Deforestation: The Case of Cross River State, Nigeria
}

\author{
Oliver 0. O. Enuoh1, Francis E. Bisong2 \\ ${ }^{1}$ Tropical Ecological Consult Ltd., Abuja, Nigeria \\ ${ }^{2}$ Department of Geography and Environmental Science, University of Calabar, Calabar, Nigeria \\ Email: oliverenuoh@yahoo.com, febisong@yahoo.com
}

Received 28 December 2014; accepted 13 January 2015; published 22 January 2015

Copyright (C) 2015 by authors and Scientific Research Publishing Inc.

This work is licensed under the Creative Commons Attribution International License (CC BY). http://creativecommons.org/licenses/by/4.0/

c) (i) Open Access

\begin{abstract}
Nigeria has lost over $\mathbf{9 0 \%}$ of her forest resources due to the hydra-headed and enduring problem of deforestation, hinging on timber logging, establishment of agricultural plantations in hitherto intact forest reserves, construction of highways, mining of solid minerals, approval of taungya farming activities in forest reserves, extraction of non-timber forest products (NTFPs), and dereservation of large areas of certain forest reserves for other economic and development activities. Though colonialism was dismantled in the first half of the twentieth century, its policies on forest nationalization remain unchanged across many independent states in the tropics including Nigeria. The paper assesses the colonial forest policy underpinnings of tropical deforestation in Cross River State of Nigeria. It highlights the weaknesses of forest reservation laws and its impacts on tropical deforestation. The paper concludes by advocating a shift in forest policies in favour of property rights recognition and devolution of forest management responsibilities to forest communities.
\end{abstract}

\section{Keywords}

Colonialism, Forests, Policies, Deforestation, Devolution and Communities

\section{Introduction}

Tropical deforestation remains one of the greatest environmental challenges of our time. It cuts across all countries in the developing world with serious impacts on biological species depletion and extinctions. Understanding the complexities of tropical deforestation and forest cover change across different developing countries re- 
mains a key area of interest in global environmental change research (Geist \& Lambin, 2001). Several researchers, reviewers and even organisations trace the problem of tropical deforestation to unchanged colonial forest policies that hinge on the nationalization of the ancestral forest lands of local communities (Guha \& Gadgil, 1989; Sivaramakrishnan, 1995; IUCN, 1996; and Fairhead \& Leach, 2000). The paper argues that tropical deforestation can be addressed effectively if policy shift de-emphasizes colonial forest policies in favour of property rights recognition and devolution of forest management responsibilities to forest communities. A key question here is why are people in the tropical world opposed to colonialism and colonial forest policies?

Colonialism is a system of extra-territorial extension of a nation's sovereignty by the establishment of either settler or exploitation colonies in which indigenous populations are directly ruled, displaced, or exterminated (Goncharov, 1963; Nkrumah, 1961). It is essentially a system of direct political, economic, cultural and religious domination of a weaker people or territory, by a more powerful nation (Horvath, 1972). The purpose of colonialism and imperialism include economic exploitation of the colony's natural resources, creation of new markets for the colonizer, and extension of the colonizer's way of life beyond its national borders (Goncharov, 1963; Guha \& Gadgil, 1989). Under colonialism, European powers entered into "treaty agreements" with illiterate African rulers who surrendered their territories to them for economic exploitation in frameworks that were to impoverish local people in perpetuity (Burns, 1929: p. 306).

In all former British colonies, the key issue in forest policy was the nationalization of the timber-rich forest lands of local communities vis-a-vis the creation of Government forest reserves (Guha \& Gadgil, 1989; Sivaramakrishnan, 1995; Colchester, 2004; Okali \& Eyog-Matig, 2004). The Indian Forest Act of 1878, which obliterated centuries of customary use of the forest by local people, became a model forest policy document for all other British colonies (Guha \& Gadgil, 1989). The above policy, anchored on the legitimacy of scientific forestry, triggered serious resistance from the affected and impoverished local people. Violent confrontations by local villagers erupted in different provinces in India e.g. in the "Gudem and Rampa hill tracts of present-day Andhra Pradesh; among the Saora tribal people of the Ganjam Agency” (Guha \& Gadgil, 1989: pp. 154-155). At the Rampa rebellion of 1879-1880, also in India, villagers attacked and burnt police stations, and "Tammman Dora (the ring leader) was shot by the Police in June 1880” (Guha \& Gadgil, 1989: pp. 154-155).

Guha \& Gadgil (1989: p. 155) further maintain that the formation of reserved forests culminated in the destruction of many villages and the eviction of their inhabitants. In order to draw attention to their grievances, "some tribesmen went on hunger strike outside the king's palace at Jagdalpur... At the same time, police stations and forest outposts were burned, stacked wood looted, and a campaign mounted against pardeshis (outsiders)." Ribot (1999) comments that "in Africa the colonial antecedents of many of today’s forestry policies were unapologetic in favouring Europeans over Africans.” In South Africa, Magome \& Murombedzi (2003: p. 109) maintain that during colonialism:

“The apartheid government passed the Natives' Land Acts of 1913 and 1936, which restricted land ownership by black people to just 13 per cent of the country's total land area."

In Ghana, Buell (1928) reports that prior to 1924, natives owned forest concessions and sold wood upon the same basis as Europeans. However the competition became so keen that in a 1924 administrative order, "the government declared that a native could not cut and sell wood except for his own use without making a deposit with the government of twenty-five hundred francs—a prohibitive sum” (Buell, 1928: p. 256). Across the colonies local resistance erupted against repressive forest policies. In Zimbabwe, Mapedza (2007: p. 833) maintains that "local resource users have not remained passive recipients of the repressive forestry policies and practices...but have actively contested them since the 1950s.” In Nigeria, Okali \& Eyog-Matig (2004: p. 8) comment that the principal activities of colonial forestry "were the selection, demarcation and constitution of suitable sites as forest reserves, and the preparation of working plans" for commercial logging activities. Under the forest reservation policies, local people were made to believe (on one hand) that the forest reserves were being held in trust for future generations, while on the other hand, state control (Mapedza, 2007), and 'timber exploitation which began in the 1880s' (Okali \& Eyog-Matig, 2004: p. 8), was the main objective. The above thus compromised the ecological values and conservation objectives of colonial scientific forestry, with local communities as witnesses.

Proof of the commercial agenda of British colonial forestry (contrary to their conservation agenda) is offered by Geary (1927: p. 133), who reports on colonial export earnings from timber exploitation in Nigeria 
between 1900 and 1913 as follows: “1900 (£7013), 1901 (£11,228), 1902 (£13,235), 1903 (£32,027), 1904 (£59,132), 1905 (£38,695), 1906 (£68,718), 1907 (£69,241), 1908 (£77,054), 1909 (£47,086), 1910 (£60,469), 1911 (£55,576), 1912 (£78,007), and 1913 (£105,440).” The British Royal Institute of International Affairs, founded in 1920, commented on timber trade in a publication in 1960 titled "Nigeria: The Political and Economic Background":

"The value of timber exports has expanded in the years of world shortage during and after the Second World War. In 1958 it amounted to over $£ 6$ million, or about 4.5\% of Nigeria’s total exports... With the recent expansion in the timber trade many small saw mills have sprung up, as well as a number of large scale enterprises. Among them the United Africa Company's highly mechanized sawmill and plywood factory at Sapele —opened in 1950—represents the largest single industrial undertaking in Nigeria, and an investment of some 22.5 million.”

In other West African countries like Ghana and Ivory Coast or Cote de Voire, the colonial administrators cornered logging concessions and the lucrative timber trade for outsiders or their European clients and marginalized the natives. For instance Buell (1928: p. 256) reports that

"Before 1924, natives held forest concessions and sold wood upon the same basis as Europeans. But the competition became so keen and native cutting so difficult to control that in a 1924 administrative order, the government declared that a native could not cut and sell wood except for his own use without making a deposit with the government of twenty five hundred francs—a prohibitive sum"

Buell (1928: p. 256) further informs that the above system was also practiced in the French Congo, culminating in "the locking up of the resources of the territory in the hands of a dozen companies." Similarly, Hailey (1938) reports that in 1930, one of the European timber companies operating in Congo, Compagnie Forestiere Equatoriale, controlled 100,000 hectares of lease concessions alone.

To underscore the role of logging in the revenue profile of British colonial India, Sivaramakrishnan (1995: p. 10) reports that "in most provinces, the Forest Service was placed administratively under the Revenue Department, a good indication of the primary role assigned to forestry.” Similarly, Stebbing (1926: p. 345) comments that the Forest Service in India became regarded "as a purely commercial concern—its chief raison d'etre the production of revenue.” Sivaramakrishnan (1995) stresses that during colonialism forest Landscapes were seen as commodities, and members of an ecosystem were treated as isolated and extractable units. He maintains that colonial forestry attracted serious resistance from local people who were generally impoverished by colonial forest reservation laws.

After several years of struggles for independence in different colonies, colonialism was dismantled after the second world war. Nigeria attained her national independence on October 1 1960. Impoverished local people and communities were made to believe by pre-independence politicians and freedom fighters across several colonies that national independence will culminate in the abrogation of colonial forest reservation laws and state recognition of local property rights. However, national independence came across former colonies, but the colonial forest reservation policies did not change, and indeed have remained unchanged to this day. In Colonial Guinea for instance, Fairhead \& Leach (2000: p. 51) comment that "politicians in the run-up elections found that they could easily rally rural support through slogans such as 'we promise to give you back your lands and forests'." That did not happen. However, some forest reserves were de-reserved to allow land to powerful politicians and certain favoured local communities and groups.

It is instructive to note that post-colonial forest de-reservation exercises were not peculiar to Colonial Guinea. It also happened in Nigeria. The bone of contention here is that powerful politicians from certain villages used their influence to de-reserve huge territories of land for themselves and their communities, while villages without powerful people could not secure de-reservation approvals, culminating in what is generally referred to as internal colonialism and injustice to this day. After the above initial phase of selective and discriminatory forest de-reservation exercises by post-independence politicians and leaders, colonial forest reservation laws became enforced with greater vigour (Fairhead \& Leach, 2000).

Post-independence continuation of colonial forest reservation policies is grounded on three key reasons. First, the European powers or colonial authorities had economic interest in the forest reserves and wood factories they had established in different colonies (e.g. the United Africa Company wood factory at Sapele, Nigeria). That is why as Goncharov (1963: p. 468) puts it "upon losing political control over the colonial territories, the imperial- 
ist powers proclaim principles of friendship, co-operation, and 'free association' with the young sovereign states”, which enabled them to exercise political and economic control over them. The second is the influence of colonial legacy on public policies and programmes in independent states. In the case of Nigeria, Heussler (1968: p. 83) comments that

"The legacy of the purely British administrative complex that overlay the grass-roots machinery of Anglo-African government is important and will remain so for many generations. No matter how much of its paraphernalia is discarded by African rulers, many things will go on being done in Nigeria, consciously or not, simply because the British did them that way."

The third reason is that post-independence governments across all newly independent states relied on the forest (timber logging) for national revenue generation. Accordingly, they had to retain colonial forest reservation policies so as to control timber exploitation and revenue generation from forest resources in general. A typical example is Ivory Coast, which since independence has pursued destructive forestry practices in order to earn foreign exchange and tax revenues (World Bank, 1985). Vandergeest \& Peluso (2006) comment that doctrines of economic development, pursued by newly independent states (after world war II), culminated in widespread unsustainable logging activities. The Food and Agriculture Organisation of the United Nations "became the key international institution supporting forestry for development" in the emergent states of the tropical world (Vandergeest \& Peluso, 2006: p. 369). Forestry Departments of independent states with limited financial and human resources took charge of commercial logging activities in frameworks that marginalised local communities in the sharing of benefits (IUCN, 1996).

Unsustainable logging activities, agriculture (slash and burn method or shifting cultivation), mining, infrastructural development (roads and railways), and urbanization are among the drivers of deforestation that cut across the developing world (McMorrow \& Talip, 2001; IUCN, 1996; and WWF/ODNRI, 1989). In Nigeria, 30 years of post-independence logging/unsustainable forestry practices (1960-1990), underpinned by unchanged colonial forest policies, culminated in the loss of over 90\% her primary forest (WWF/ODNRI, 1989). The above underscored the need for conservation measures to stem the tide of deforestation and loss of biodiversity.

\section{Methods}

This paper is the qualitative part of a 2012 study that assessed biodiversity conservation and deforestation challenges in Cross River National Park of South Eastern Nigeria. A combination of qualitative and quantitative research techniques (mixed methods approach) was applied in the study. Two buffer zone communities and one non-buffer zone community (for comparative purposes) were purposively sampled for the study. Purposive sampling was deemed appropriate in order to concentrate on communities with more serious evidence of deforestation and land cover change. The qualitative data was obtained through Document research, interviews, focus group discussions, and participatory rural appraisal (PRA) exercises.

The quantitative data on the other hand was obtained through rural livelihoods survey in the study communities and GIS (Geographic Information System) data from the Cross River State Forestry Commission. Due to unreliable census figures and voters register in Nigeria, a total of 360, 308 and 400 households were compiled at Old Ekuri, Abo Mkpang and Akwa Ibami villages respectively. Proportional to the above number of households per village, a formula of one in four households was used to generate a sample population of 90 (Old Ekuri), 77 (Abo Mkpang), and 100 (Akwa Ibami), resulting in a total sample size of 267.

\section{Results}

\subsection{Colonial Nationalization and Commodification of the Forest Estate}

A careful assessment of historical time line information (Table 1) on forest resources use and management in Nigeria reveals that the British colonial forest policy of nationalization in the 1930s was followed by the commencement of mechanized logging and deforestation in government forest reserves in the 1940s. Examples of pioneering British logging companies involved include UAC (United African Company) Ltd, Brandler and Rylke Ltd, Cobbett \& Co Ltd, Glikstens Ltd, Finch \& Co Ltd, etc. On the scale of logging concessions controlled by UAC in Western Nigeria, for instance, Brandler (1995: p. 77) observes that "The United African 
Table 1. Cross River State of Nigeria: time line on forest resources use and management.

\begin{tabular}{|c|c|}
\hline DATE & EVENTS \\
\hline 1844 & Abolition of slavery and slave trade (Rotberg, 1965). \\
\hline 1851 & $\begin{array}{l}\text { British conquest of Lagos (Southern Nigeria), and commencement of control of } \\
\text { economic activities in the region (Burns, 1929). }\end{array}$ \\
\hline 1855 & The Berlin treaty of 1855 gives the part of West Africa, now known as Nigeria to Britain (Idowu, 2008). \\
\hline 1861 & Lagos (Southern Nigeria) formally becomes a British Colony (Burns, 1929). \\
\hline 1879 & $\begin{array}{l}\text { Royal Niger Company, founded by Sir George Taubman Goldie, begins legitimate trade activities on commodities } \\
\text { (e.g. Palm Oil and Palm Kernel) in southern Nigeria, culminating in the establishment of oil palm plantations and } \\
\text { commencement of deforestation in Nigeria (Burns, 1929). }\end{array}$ \\
\hline 1900 & Formation of the protectorates of Southern and northern Nigeria (Burns, 1929). \\
\hline 1914 & Amalgamation of the Southern and Northern Protectorates, under the name Nigeria (Burns, 1929). \\
\hline 1930s & $\begin{array}{l}\text { Colonial forest policy (forest nationalisation) introduced: creation of Government Forest Reserves and Community } \\
\text { Forest. Communities protested but Colonial Authorities explained that Government Forest Reserves were neces- } \\
\text { sary to reserve some forest for future generations. Government was holding the forest (in trust) for the people } \\
\text { (CRS Forestry Commission). }\end{array}$ \\
\hline 1940 s & $\begin{array}{l}\text { Logging concessions and logging licenses in several Government Forest Reserves in Western Nigeria (e.g. Ondo } \\
\text { province) granted UAC (united African Company), culminating in the establishment of Sawmills and Plywood } \\
\text { factories, and the commencement of large scale deforestation in Western Nigeria. }\end{array}$ \\
\hline 1950s & $\begin{array}{l}\text { Brandler and Rylke Ltd, London commences mechanised timber logging activities in Eastern Nigeria. Logging } \\
\text { concessions granted by Government in Government Forest Reserves. Sawmills established in different places, e.g. } \\
\text { Apiapum in Cross River State, Nigeria. Communities alarmed by deforestationcaused by Brandler \& Rylke. } \\
\text { Establishment of several Government Oil Palm, Rubber and Cocoa plantations e.g. Calaro, Ayip Eku, CREL, } \\
\text { ONREL, IBIAE, Borum, etc and the exacerbation of deforestation (CRS Forestry Commission). }\end{array}$ \\
\hline 1960s & $\begin{array}{l}\text { Nigeria became independent on October } 1^{\text {st }}, 1960 \text {. Forestry Departments became major revenue agencies of Gov- } \\
\text { ernment through timber logging activities. Government established wood industries e.g. Seromwood Industries \& } \\
\text { Calabar Veneer and Plywood factory (CRS Forestry Commission). }\end{array}$ \\
\hline 1970s & $\begin{array}{l}\text { End of Nigerian Civil War (January } 15^{\text {th }}, 1970 \text { ), and more pressure on the forest for revenue. In Cross River State, } \\
\text { several companies granted logging concessions in Government Forest Reserves e.g. Hanseatic Ltd, Isulight Ltd, } \\
\text { Kisari Ltd, Ikobi brothers Ltd, and Magnificat Ltd (CRS Forestry Commission). }\end{array}$ \\
\hline 1980-1990 & $\begin{array}{l}\text { Nigeria has lost } 90 \% \text { of her forest (WWF/ODNRI, 1989). } \\
\text { Creation of Cross River National Park, in } 1989 \text { (CRNP). }\end{array}$ \\
\hline $1991-2000$ & $\begin{array}{l}\text { ODA Forestry Project in Cross River State (1991-1994) and Bisong (1994). } \\
\text { DFID Community Forestry Project in Cross River State (1999-2002) (CRS Forestry Commission). }\end{array}$ \\
\hline 2001-2011 & $\begin{array}{l}\text { Logging ban and closure of WEMPCO, a Chinese logging factory at Ikom, Cross River State, Nigeria in } 2004 \\
\text { (CRS Forestry Commission). } \\
\text { Commencement of Cross River State UN-REDD negotiations in 2009. } \\
\text { Micro level illegal logging challenges. No livelihood programmes (CRS Forestry Commission). }\end{array}$ \\
\hline
\end{tabular}

Source: Field work 2012.

Company, which had licenses for many Government Forest Reserve areas, had constructed a narrow gauge railway and used it to evacuate logs over twenty miles, to a waterside at Okiti Pupa from where they rafted logs to Sapele port. That was quite an exception in those days. Later, Caterpillars and Trucks were used for the extraction of timber and this extraction criss-crossed the forests faraway from water (or sea port)."

During participatory compilation of this historical time line (Table 1), villagers lamented that after Nigeria's independence on October $1^{\text {st }} 1960$, government has over the years been acting as both conservator and destroyer of the forest, anchored on the colonial example on forest reservation, subsequent commodification of timber resources and large-scale mechanized logging in Government Forest Reserves. After national independence, Forestry Departments in Nigeria, with limited capacity to manage the several forest reserves that were placed under their jurisdictions, became revenue earners for government, resulting in continuous annual approval of logging concessions to timber companies. The logging concessions were not backed up by re-planting or reforestation programmes.

In Cross River State 12 out of the 17 Government Forest Reserves established by the British became almost 
completely cleared between 1960-1990 due to logging concessions and logging activities carried out unsustainably by timber companies. During an interview, a key informant at the Cross River State Forestry Commission gave examples of timber companies that operated in Cross River State to include Brandler and Rylke Ltd, Seromwood Industries Ltd, Calabar Veneer and Plywood Ltd, Mikes Wood Ltd, Kisari Ltd, Hanseatic Ltd, Isulight Ltd, Fouplant Ltd, Magnificat Ltd, Ikobi brothers Ltd, Rite-Edge Ltd, Wempco Ltd, and several private individuals that registered as timber dealers with the Forestry Commission in Calabar-the capital of Cross River State. The current level of deforestation in Cross River State is presented in the map in Figure 1.

A comparison of the above map (Figure 1) with other versions e.g. that of 1960 (Figure 2) (at the time of Nigeria's independence) shows that tropical high forest (green colour) occupied a larger part of Cross River State in the past than the present as shown in the above (current map).

A forest inventory report obtained at the Cross River State Forestry Commission in 2012 reveals disturbing levels of deforestation in government forest reserves as presented in Table 2.

\subsection{Agricultural Practices, Government Plantations and Deforestation}

The practice of slash and burn agriculture by farmers in local communities and colonial government establishment of tree-crop agricultural plantations (e.g. cocoa, rubber, oil palm, cashew and gmelina) in hitherto intact government forest reserves, have exacerbated tropical deforestation in Nigeria in general and Cross River State in particular. In Cross River State, examples of government tree crop agricultural plantations include Calaro oil palm estate, Cross River Rubber Estates Limited, Ayip-Eku oil palm estate, Ibiae oil palm estate, Biakpan rubber estate, Agoi rubber estate, Nko rubber estate, Borum oil palm estate, Oban oil palm rubber estate, and Ikom cocoa estates. There are also several private tree crop plantations for cocoa, rubber, oil palm, and cashew nuts across the eighteen local government areas in Cross River State which have seriously impacted on deforestation levels in the state.

The Cross River State Forestry Commission Law of 1999 provides for permission to individuals to farm in government forest reserves on a few of N2500.00 (or \$10) per hectare. On the strength of the above, several parcels of government forest reserve lands are now tacitly controlled by private individuals who have cleared

Table 2. Status of vegetation in government forest reserves in cross river state.

\begin{tabular}{|c|c|c|c|c|c|c|}
\hline \multirow{2}{*}{$\begin{array}{l}\text { Name of Forest } \\
\text { Reserve }\end{array}$} & \multirow[b]{2}{*}{ Area (ha) } & \multicolumn{5}{|c|}{ Vegetation types (\%) } \\
\hline & & High Forest & Swamp forest & Gmelina & $\begin{array}{c}\text { Other plantations } \\
\text { (Rubber, Oil palm, \& other plantation trees) }\end{array}$ & $\begin{array}{l}\text { Cleared (land with } \\
\text { few or no trees) }\end{array}$ \\
\hline Afi River & $38,330^{*}$ & 89 & & & & 11 \\
\hline Agoi & $5780^{*}$ & 67 & & & & 33 \\
\hline Cross River North & $12,950^{*}$ & 54 & & & 5 & 41 \\
\hline Cross River South & $24,200^{+}$ & 99 & & & & 1 \\
\hline Ekinta River & $10,400^{*}$ & 4 & 5 & 2 & & 89 \\
\hline Gabu & $550^{*}$ & & & 100 & & \\
\hline Ikrigon & $600^{*}$ & & & & 100 & \\
\hline Oban Group & $104,200^{+}$ & 67 & 1 & $>1$ & 10 & 22 \\
\hline$\underline{\text { Oban Division }}$ & $274,800^{+}$ & 97 & & & & 3 \\
\hline Okwangwo Div. & $80,900^{+}$ & 80 & & & & 20 \\
\hline Ukpon River & $31,380^{*}$ & 76 & & 8 & & 16 \\
\hline Umon Ndealeachi & $11,430^{*}$ & 35 & 16 & & & 49 \\
\hline Uwet Odot & $24,490^{*}$ & 39 & 19 & 4 & & 38 \\
\hline Yache & $1660^{*}$ & & & 100 & & \\
\hline
\end{tabular}

Source: Cross River State Forestry Project (ODA-Assisted)—Forest Inventory Report, 1994. Footnotes: ${ }^{*}=$ Areas taken from Sutter (1979) Table A10.8. $;^{+}=$Areas taken from IDRISI maps rounded to nearest 100 ha. 


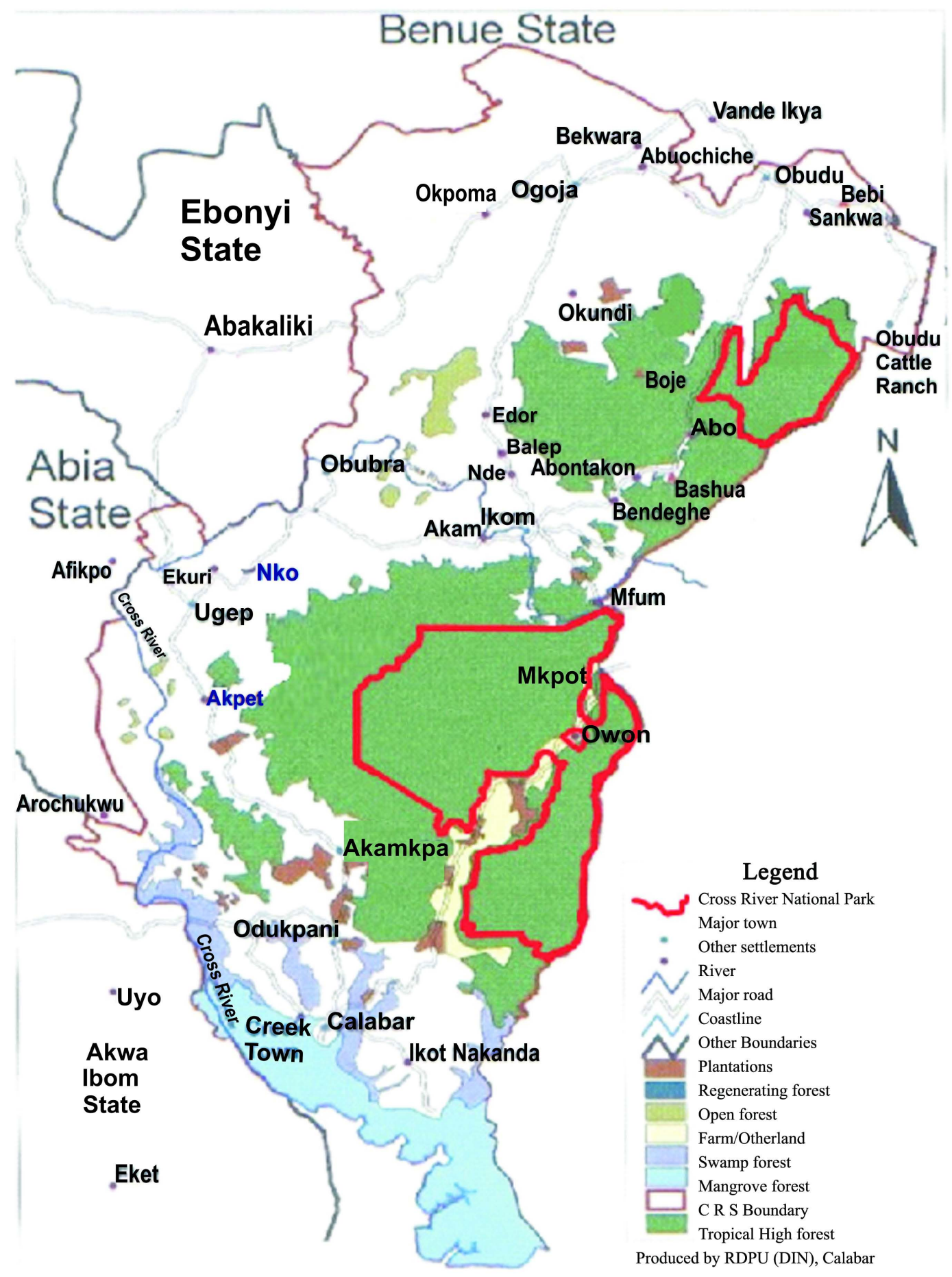

Figure 1. Map showing current deforestation in cross river state of Nigeria.

several hectares of pristine forest for agricultural purposes. Closely related to the above is taungya farming system which was approved by the Forestry Commission in government forest reserves in the 1980s. The taungya farming system allowed individuals to clear primary forest for food crop cultivation combined with exotic tree species needed by government (e.g. teak and gmelina arborea). This culminated in serious deforestation in the state. Commenting on colonial forest policies and forest clearance through taungya farming system in Cross River State, Dunn and Otu (1996: p. 35) maintain that 


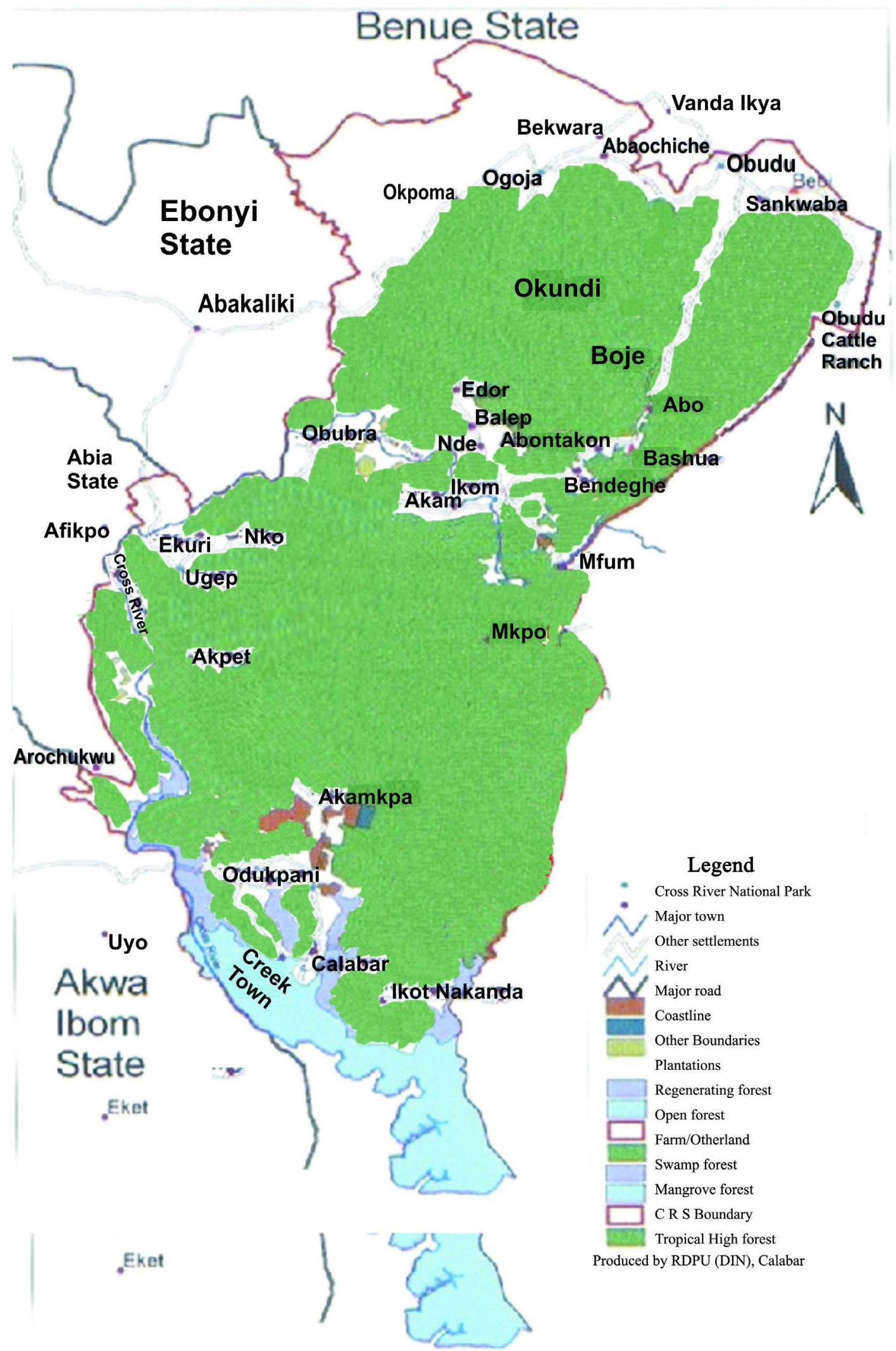

Figure 2. Map showing forest cover in cross river state of Nigeria (1960). 
"Ekinta, an 11,000 hectare forest reserve in the south east of the state, provides a good example of accelerated high forest loss as a consequence of forest policy that favoured forest exploitation and the establishment of fast-growing exotic species. The reserve was good quality high forest until the late 1970s. The government-owned logging company Seromwood cleared much of the forest in a salvage cut and opened up the entire reserve with a network of roads. A large number of farmers from the then south west of Cross River State (now the neighbouring state of Akwa Ibom) were permitted to move into the area to establish plantations of Gmelina arborea using the taungya system. However, due to a shortage of funds for seedlings and supervision, virtually no plantations were established. In less than a decade, 90\% of the forest reserve had become cassava farms instead of forest plantations with hardly a tree standing."

From the above forest loss, this paper stress that colonial forest reservation policies (which have remained unchanged to this day) have exacerbated tropical deforestation in Cross River State in particular and Nigeria in general.

\subsection{Equations Uncontrolled Extraction of Non-Timber Forest Products (NTFPs)}

The tropical rainforest of Cross River State is extremely rich in revenue yielding non-timber forest products (NTFPS) which include wild edible vegetables, wild edible fruits, medicinal plants, fuel wood, building materials, arts and craft materials, bushmeat and local tools and equipments. The list of income yielding NTFPs in Cross River State is presented in Table 3.

\subsection{Highway Construction and Mining of Solid Minerals}

The construction of state and federal highways across hitherto intact government forest reserves in Cross River State and mining of solid minerals have contributed immensely in worsening the rate of tropical deforestation in the state. Examples of federal highways in the state include Calabar-Ikom-Ogoja road, Ogoja-Obudu-Ikom road, Calabar-Oban-Ekang road, Calabar-Itu-Ikot Ekpene road, and Ikang-Calabar road. State roads are numerous cutting across the eighteen local government areas in Cross River State. The government forest reserves that have witnessed different levels of deforestation due to highway construction and mining of solid minerals (e.g. limestone, barites, gravels, and granites) include Cross River North Forest Reserve, Cross River South Forest Reserve, Ukpon River Forest Reserve, Afi River Forest Reserve, Umon-Ndealichi Forest Reserve, Uwet-Odot Forest Reserve, Okwangwo Forest Reserve and Ekinta Forest Reserve.

Public highways have created different locations of trespass into government forest reserves, making it difficult to check or control illegal activities by various offenders. The offences include illegal logging, mining, farming, hunting of animals, and extraction of different non-timber forest products. During an interview, a senior officer at the Cross River State Forestry Commission commented that poor funding, inadequate staff, and lack of four wheel drive vehicles make it difficult to undertake regular patrols in government forest reserves by forest rangers. The above officer lamented that the ten Land Rovers (four wheel drive vehicles) that were donated to the commission by the British Overseas Development Administration (ODA) in 1991 had all broken down. Staff of the Forestry Commission are thus, unable to undertake regular field visits across rough and hilly forest roads to check illegal activities in forest reserves.

\subsection{De-Reservation of Large Portions of Some Government Forest Reserves}

De-reservation applications and approvals by the Forestry Commission have over the years contributed seriously in increasing the rate of tropical deforestation in government forest reserves in Cross River State. De-reservation is a process where formal application for land in government forest reserves by private individuals and communities is approved by the Forestry Commission culminating in the re-adjustment of forest reserve boundaries to allow individuals or communities to own more land. Not everybody or community that applies for de-reservation gets an approval. Usually the approval goes to powerful politicians, businesses, and influential chiefs and communities. Due to the sensitive nature of de-reservation exercises, the Forestry Commission usually keep it confidential. The number of hectares that have been de-reserved remain unknown. However, a key informant mentioned that de-reservation approvals have taken place in government forest reserves such as Cross River North, Cross River South, Agoi, Afi River, and Oban group forest reserves. 
Table 3. List of some non-timber forest products in cross river state.

\begin{tabular}{|c|c|c|c|}
\hline S/No. & Common Name of NTFP. & Botanical Name & When Harvested \\
\hline \multirow[t]{7}{*}{1.} & Vegetables: & & All year \\
\hline & (a). Salad/Affang/Okasi & Gnetum Africana & All year \\
\hline & (b). Hot leave/Seeds & Piper Guineensis & “” \\
\hline & (c). Atama (Efik) & Heinsia Crinata & “” \\
\hline & (d). Editan (Efik) & Lasianthera Africanum & “” \\
\hline & (e). Bitter leaf & Veronina sp. & “” \\
\hline & (f). Wild bitter leaf/Otasi & Gongronema latifolum & \\
\hline 2. & Mushrooms (assorted) & & Rainy/Dry season. \\
\hline 3. & Water Periwinkles & & All year. \\
\hline 4. & Giant land snails & Litorina sp. & Rainy season \\
\hline \multirow[t]{2}{*}{5.} & Bush mango (sweet) & Archachantina marginata & Rainy season \\
\hline & Bush mango (bitter) & Irvingia gabonensis & Dry season \\
\hline 6. & Poga & Irvingia gabonensis & All year \\
\hline 7. & Chest nut & & All year \\
\hline \multirow[t]{2}{*}{8.} & Fish (assorted) & & All year \\
\hline & Crab & & All year \\
\hline \multirow[t]{3}{*}{9.} & Nature Kola & Cancridae & Rainy season \\
\hline & Native Kola & Cola lepidata & Rainy season \\
\hline & Bitter Kola & Cola acuminate & Rainy season \\
\hline 10. & Ikaba (Efik) & Cola nitida & Rainy season \\
\hline 11. & Uyayak (Efik)-spices & Mucuna swaneii & Dry season \\
\hline 12. & Foaming Chewing Stick & Tetrapleura Tetraptera & All year \\
\hline 13. & Cane Rope & Randia sp. & All year \\
\hline 14. & Shell nut (Enoi-Efik) & Eremospatha macrocarpa & All year \\
\hline 15. & Ndiya (Efik) & Poga Oleosa & Rainy season \\
\hline 16. & Palm Kernel & Coula edulis & All year \\
\hline 17. & Wrapping leaf & Elais guineensis & All year \\
\hline 18. & Nfong (Efik) & Thaumato-coccus & Dry season \\
\hline 19. & Bush Pear & Afromomum sp. & Rainy season \\
\hline 20. & Achi seeds & Canarium Schwenfurthii & Dry season \\
\hline 23. & Ukana fruit & Brachystegia & Dry season \\
\hline 24. & Ekom (Efik) & Penthacletra sp. & Rainy season \\
\hline 25. & Calamus. & Eremospatha sp. & All year \\
\hline 26. & African Locust Bean & Parkia Biglobosa & Dry season \\
\hline \multirow[t]{2}{*}{27.} & Alligator Pepper (hot) & Afromomum meleguata & All year \\
\hline & Alligator Pepper (Sweet) & hanburyi & All year \\
\hline 28. & Mimusops & Baillonella Toxisperma & Rainy season \\
\hline 29. & Bush Onion & Afrostyrax lepidophyllus & Rainy season \\
\hline 30. & Elephant Mushroom & Pleurotus tuberosus & Dry season \\
\hline 31. & Ethiopian Pepper & Xylopia aethiopcia & Rainy season \\
\hline 32. & Bush Pumpkin & Telferia sp. & All year \\
\hline 33. & Bush Pepper & Piper guineensis & Rainy season \\
\hline 34. & Small land snail & Helix pomatia & All year \\
\hline 35. & Sponge & Momordica augustisepala & All year \\
\hline 36. & Wild Honey & Apis mellifera/Apidae & All year \\
\hline 37. & Camwood dye & Pterocarpus Osun & All year \\
\hline 38. & African Oil Bean & Pentaclethra macrophylla & \\
\hline 39. & Randia (chewing stick) & Massularia acuminate & All year \\
\hline 40. & Rattan Cane & Laccosperma secundiflora & All year \\
\hline \multirow[t]{2}{*}{41.} & Raphia Palm & Raphia hookeri & All year \\
\hline & Raphia Bamboo & Raphia vinifera & All year \\
\hline 42. & Cattle Stick & Carpolobia lutea & All year \\
\hline 43. & Native dye & Rothmania hispidia & All year \\
\hline
\end{tabular}

Source: Fieldwork, 2012. Frequent and uncontrolled harvesting of the above NTFPs in forest communities is also contributing towards tropical deforestation in Cross River State. 


\subsection{Foresters and Resistance to Decentralized Forest Management}

Attempts to address deforestation challenges in Cross River State through devolution of forest management responsibilities to communities has been strongly resisted by foresters in the state Forestry Commission. A key informant commented that between 1991-1994, the British Overseas Development Administration (ODA, now DFID), was involved in a forestry project that assessed tropical deforestation challenges and forest management approaches in Cross River State, Nigeria. In a strategy document and final ODA project report in November 1994, the weaknesses of centralized forest management was recognised as major cause of widespread illegal logging activities and deforestation in the state. The report finally recommended community forestry, or devolution of forest management responsibilities to communities, as the best way forward. Accordingly, a second phase ODA (DFID) forestry project was strongly recommended to midwife community forestry in the state. Opposition to community forestry by some foresters was noted but ignored.

During the second phase ODA (DFID) forestry project, tagged Cross River State Community Forestry Project-DFID Assisted (1999-2002), some foresters openly declared that community forestry was a threat to their profession because the project entailed devolving forest management responsibilities to communities. Foresters were expected to be involved in redefined roles that included supervisory, technical assistance, and capacity building of villagers to protect and manage forest lands. The establishment of community-based forest management organisations with clearly defined roles, forest policy change, and capacity building initiatives were to be major areas of focus for the above community forestry project. The first project manager employed by DFID came with a mindset to implement the community forestry project as explained above. He met with stiff resistance by foresters which made him resign and went back to the UK.

A second project manager was engaged who agreed with foresters to experiment a community forestry model where Forest Management Committees (FMCs) are established in forest communities to handle certain forest management responsibilities (e.g. arrest of illegal loggers), while foresters remain responsible for forest management as had always been the case. As committees, FMCs could be set up and dissolved at anytime by foresters. In contrast, registered community organisations (as legal entities with bye-laws) and formal/institutionally sustainable ways of doing things, were feared by foresters as capable of taking over the forestry profession from the professionals and giving it to forest communities. The DFID Community Forestry Project accordingly established 22 FMCs across major forest communities in Cross River State, carrying out roles assigned to them by foresters. Suffice to mention that the FMC experiment failed to protect and manage the forest resources of Cross River State as soon as the DFID Community Forestry Project came to an end in 2002. To this day there are no success stories of the FMC approach to community forestry. Tropical deforestation challenges are ubiquitous and persist in Cross River State to this day, with government monopoly in forest management reigning supreme.

\section{Discussion}

In the study, analysis and understanding of tropical deforestation and land cover change, different researchers from different disciplinary backgrounds, have adopted different approaches which link the problem to different causes. This paper addresses the colonial forest policy underpinnings of the problem drawing insights and evidence from Cross River State of Nigeria. The key question is, does colonial forest policy matter in the quest of understanding and addressing the causes of tropical deforestation? From the perspective of this paper, the simple and direct answer is yes. Most, if not all of the developing countries in the tropical world were former European colonies where colonial forest policies were used in forest resources governance. Forest nationalization and subsequent introduction of mechanised logging in government forest reserves-a common currency of colonial forest policies, laid the foundation of large scale deforestation in most, if not all tropical nations.

Though colonialism was dismantled during the first half of the twentieth century, all indigenous governments in the new and independent nations retained the forest reservation policies of the colonial era. The social tensions, protests, and property rights struggles that defined and characterised local people's relationship with colonial forest polices and forest resources governance spilled over to the post-colonial era. Post-colonial governments of independent nations gave out several government forest reserves to logging companies as logging concessions in order to generate and sustain government revenue. Local communities with limited legal rights stood by, watching large scale mechanised logging and deforestation that was characterised by the construction of roads and highways into hitherto intact government forest reserves.

Towards the end of the $20^{\text {th }}$ century, tropical deforestation and its effects on biological species depletion and 
extinction became a global environmental problem. International initiatives to address tropical deforestation challenges included a paradigm shift towards decentralization or devolution of forest management responsibilities to local communities. Examples in sub-Saharan Africa include community forestry initiatives in Liberia, Ghana, Cameroon, Uganda, Zimbabwe, and Nigeria. Koffa (2012) maintains that the devolution of forest management responsibilities in Liberia to communities has resulted in enhanced forest protection and policing of illegal logging activities in the country. In the case of Cross River State of Nigeria, attempts to introduce community forestry or community-based forest resources management by the UK DFID met with serious resistance from government foresters. A DFID community forestry project in Cross River State that would have witnessed the emergence and empowerment of community forest management organisations (in forest resources management), became enmeshed in foresters' resistance that culminated in a common ground constitution of forest management committees (FMCs) in selected forest communities (with foresters still in control). This became an experiment of a new community forestry model. The lack of a single success story in the FMC approach to community forestry (to this day), and the persistent problem of illegal logging and tropical deforestation in Cross River State of Nigeria, makes the approach a failure.

Nigeria and other tropical nations that are critical of the devolution of forest management responsibilities to communities should learn from the Philippines where forest management responsibilities are devolved to empowered community forest management organisations. In Liberia for instance, community forestry was preceded by the enactment of a Community Rights Law (CRL) in respect of the country's forest lands; establishment and empowerment of community organisations; devolution of forest management roles to communities; and re-structuring the role of Forestry Departments to include monitoring and evaluation of community forestry programmes; conflict resolution amongst communities; forest management training; organisational capacity building programmes for registered community forest management organisations; funding and donor support for community forestry; and revocation of forest management authority of any community forest management organisation that violates the Forest Management Agreement signed between the community and the Forestry Department.

Local communities depend on forest resources for their livelihoods and remain perpetually committed to the conservation and sustainable management of forest resources. This is not the case with some foresters. In most cases some foresters come from other parts of a country or state where forest has been completely cleared. Their interest is usually anchored on additional income that they can generate from timber companies and logging concessions, in order to complement their low or inadequate salaries. In such scenarios, several foresters disagree with their colleagues who are pro-conservation, and insist on continuous control of forest resources management, not for purposes of enhancing the global sustainable development agenda, but to secure their rent seeking behaviour in the management of forest concessions. In order to stem the tide of tropical deforestation, devolution initiatives in favour of the above Liberia-style community forestry programme, which is anchored on the property rights of forest communities or community rights law (CRL), remains a sine qua non.

\section{Conclusion}

Tropical deforestation and land cover change is deeply rooted in the colonial nationalization of the forest resources of local communities-a policy that has remained unchanged to this day in Nigeria, even when colonialism was dismantled in the first half of the twentieth century. Colonial forest policies introduced the establishment of government forest reserves in the 1930s (holding the forest in trust for future generations). Unfortunately, the same colonial forest policies betrayed the above trust in the 1940s, following the introduction of mechanised logging via logging concessions in government forest reserves. Mechanised logging laid the foundation for large scale deforestation in tropical nations including Nigeria.

Nigeria has lost over $90 \%$ of her forest resources due to colonially rooted practices which include not only mechanised logging, but establishment of government agricultural plantations (e.g. cocoa, rubber and oil palm), construction of highways, and mining of solid minerals. With evidence from Cross River State, post independent governments have de-reserved large portions of certain government forest reserves, and have failed to control the exploitation of non-timber forest products (NTFPs), resulting in serious tropical deforestation. In line with international paradigm shift in favour of devolution of forest management responsibilities to communities, attempts to introduce community forestry or community-based forest resources management in Cross River State of Nigeria, by the UK DFID, met with serious resistance from government foresters. 
A DFID community forestry project in Cross River State that would have witnessed the emergence and empowerment of community forest management organisations (in forest resources management), became trapped in foresters' resistance that culminated in the formation of forest management committees (FMCs) in selected forest communities (with foresters still in control). This became an experiment of a new community forestry model. The paper argues that the lack of a single success story in the FMC approach to community forestry (to this day), and the persistent problem of tropical deforestation in Cross River State of Nigeria, makes the approach a failure. The paper further argues that local communities who depend on forest resources for their livelihoods are more committed to sustainable forest management than foresters who wish to dominate forest management in order to secure their economic interests. In order to stem the tide of tropical deforestation the paper strongly recommends the adoption of the Liberia-style community forestry model, where forest management responsibilities are devolved via legal agreements to empowered community forest management organizations.

\section{References}

Bisong, F. E. (1994). Farming Systems, Human Ecology and Biodiversity Conservation in the Cross River State Rainforest of Nigeria. Ph.D. Thesis, Port Harcourt: Department of Geography, University of Port Harcourt.

Brandler, J. L. (1995). Out of Nigeria-Witness to a Giant's Toils. London: The Radcliffe Press.

Buell, R. L. (1928). The Native Problem in Africa, Vol 1 and 2. New York: MacMillan.

Burns, S. A. (1929). History of Nigeria. London: George Allen \& Unwin Ltd.

Dunn, R. M., \& Otu, D. (1996). A Community Forest Inventory for Productive Forest Management in Cross River State, Nigeria. In J. Carter (Ed.), Recent Approaches to Participatory Forest Resource Assessment. London: Overseas Development Institute (ODI).

Fairhead, J., \& Leach, M. (2000). Desiccation and Domination: Science and Struggles over Environment and Development in Colonial Guinea. The Journal of African History, 41, 35-54. http://dx.doi.org/10.1017/S0021853799007641

Geary, W. M. N. (1927). Nigeria under British Rule. London: Routledge.

Geist, H. J., \& Lambin, E. F. (2001). What Drives Deforestation? A Meta-Analysis of Proximate and Underlying Causes of Deforestation Based on Sub-National Case Study Evidence. LUCC Report Series No. 4. Belgium: University of Louvain.

Goncharov, L. (1963). New Forms of Colonialism in Africa. The Journal of Modern African Studies, 1, 467-474. http://dx.doi.org/10.1017/S0022278X00001397

Guha, R., \& Gadgil, M. (1989). State Forestry and Social Conflict in British India. Past \& Present, 123, 141-177. http://dx.doi.org/10.1093/past/123.1.141

Hailey, L. (1938). An African Survey: A Study of Problems Arising in Africa South of the Sahara. London: Oxford University Press.

Heussler, R. (1968). The British in Northern Nigeria. London: Oxford University Press.

Horvath, R. J. (1972). A Definition of Colonialism. Current Anthropology, 13, 45-57. http://dx.doi.org/10.1086/201248

IUCN (The World Conservation Union) (1996). Communities and Forest Management with Recommendations to the Intergovernmental Panel on Forests. Washington DC: IUCN.

Koffa, S. N. (2012). Community Forestry: An Epitome of Decentralized Forest Governance in Liberia. The Forest Governance Forum, Monrovia, 29 March 2012.

Magome, H., \& Murombedzi, J. (2003). Sharing South African National Parks: Community Land and Conservation in a democratic South Africa. In W. M. Adams, \& M. Mullingan (Eds.), Decolonizing Nature-Strategies for Conservation in a Post-Colonial Era. London: Earthscan Publications Ltd.

Mapedza, E. (2007). Forest Policy in Colonial and Post-Colonial Zimbabwe: Continuity and Change. Journal of Historical Geography, 33, 833-851. http://dx.doi.org/10.1016/j.jhg.2006.10.022

McMorrow, J., \& Talip, M. A. (2001). Decline of Forest Area in Sabah, Malaysia: Relationship to State Policies, Land Code and Land Capability. Global Environmental Change, 11, 217-230. http://dx.doi.org/10.1016/S0959-3780(00)00059-5

Nkrumah, K. (1961). I Speak of Freedom: A Statement of African Ideology. London: Mercury Books.

ODNRI/WWF (1989). Cross River National Park Oban Division: Plan for Developing the Park and its Support Zone. London: ODNRI/WWF.

Okali, D., \& Eyog-Matig, O. (2004). Rainforest Management for Wood Production in West and Central Africa. A Report Prepared for the Project: Lessons Learnt on Sustainable Forest Management in Africa. Rome: Food and Agriculture Organization (FAO)/African Forest Research Network (AFORNET)/Royal Swedish Academy of Agriculture and Forestry 
(KSLA) Project.

Ribot, J. C. (1999). Decentralization, Participation and Accountability in Sahelian Forestry: Legal Instruments of Central Political-Administrative Control. Africa, 69, 23-65. http://dx.doi.org/10.2307/1161076

Sivaramakrishnan, K. (1995). Colonialism and Forestry in India: Imagining the Past in Present Politics. Comparative Studies in Society and History, 37, 3-40. http://dx.doi.org/10.1017/S0010417500019514

Stebbing, E. P. (1926). The Forests of India (Vol. 1). London: John Lane.

Vandergeest, P., \& Peluso, N. L. (2006). Empires of Forestry: Professional Forestry and State Power in Southeast Asia, Part 2. Environment and History, 12, 359-393.

World Bank (1985). The Distribution of Welfare in Cote d'Ivoire in 1985. Washington DC: World Bank. 
Scientific Research Publishing (SCIRP) is one of the largest Open Access journal publishers. It is currently publishing more than 200 open access, online, peer-reviewed journals covering a wide range of academic disciplines. SCIRP serves the worldwide academic communities and contributes to the progress and application of science with its publication.

Other selected journals from SCIRP are listed as below. Submit your manuscript to us via either submit@scirp.org or Online Submission Portal.
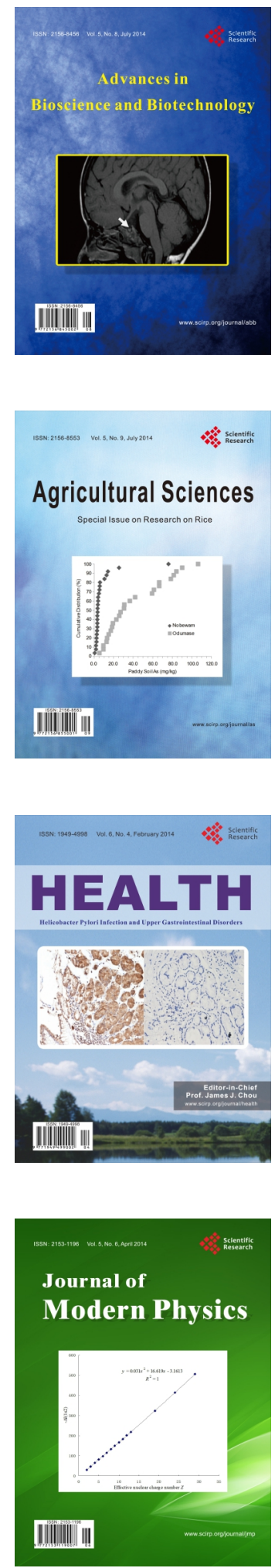
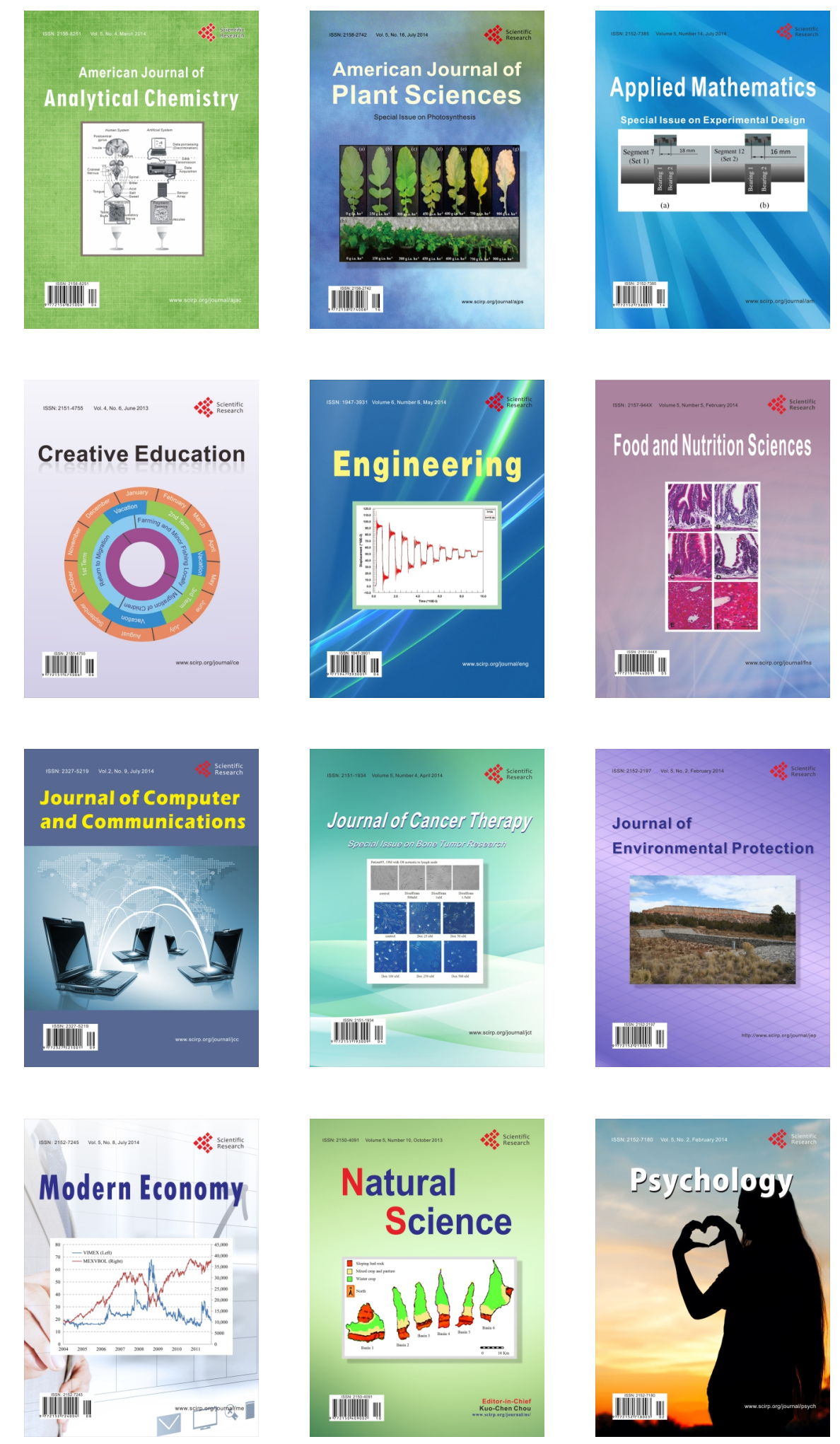